\title{
LAND RECLAMATION BY REFORESTATION IN THE CENTRAL PYRENEES
}

\author{
Luis M. Ortigosa ${ }^{1}$, Jose M. Garcia-Ruiz ${ }^{2}$, and Eustaquio Gil ${ }^{2}$
}

ABSTRACT The outmigration that has taken place in the Central Pyrenees since the 1950s has resulted in a great reduction in the rural population and the abandonment of extensive areas. Reforestation has been undertaken by various authorities to ensure the reclamation of this land. This paper discusses the recent history of reforestation, the techniques used, and the environmental factors involved. It concludes with an overview of the results of these policies and the success in creating new forested land.

RÉSUMÉ Mise en valeur des terres par reboisement dans les Pyrénées centrales. L'émigration que s'est produite dans les Pyrénées centrales depuis les années 1950 a provoqué une baisee importante de la population rurale et l'abandon de grandes étendues de terrain. Le reboisement a été entrepris par divers organismes pour assurer la mise en valeur de ces terres. Cet article examine l'historique récent du reboisement, les techniques utilisées, et les facteurs environnementaux mis en jeu. Il conclut en passant en revue les résultats de cette politique et la mesure dans laquelle celle-ci a réussi a créer de nouvelles forêts.

zUSAMMENFassung Landrüchgewinnung durch Aufforstung in den Zentralpyrenäen. Seit den 50er Jahren führt Abwanderung in den Zentralpyrenäen zu einem starken Rückgang in der Landbevölkerungszahl, und ausgedehnte Landgebiete wurden verlassen. Zur Rückgewinnung dieser Landflächen haben verschiedene Behörden Anstrengungen zur Aufforstung übernommen. Dieser Beitrag diskutiert neuere Entwicklungen bei der Aufforstung, die dabei angewandten Methoden und die zu berücksichtigenden Umweltfaktoren. Eine Prognose über die Ergebnisse solcher Unternehmungen und ihre Erfolgschancen bei der Schaffung neuer Waldflächen wird gegeben.

RESUMEN Restauración del territorio mediante la reforestación en los Pirineos Centrales. Desde la década de los cincuenta, el inicio de la más acusada emigración, redujo la población rural y con ella el abandono de las áreas de utilización más extensiva. Para asegurar la restauración del territorio vacío, diversos tipos de administración tomaron a su cargo la referida tarea. En el presente estudio, se relata la historia reciente de dicha labor de reforestación, las técnicas utilizadas y los factores ambientales implicados. Se concluye con una revisión de resultadoes referidos a dicha política y comentando los logros en la ejecución de tal labor de repoblación forestal.

\section{LAND RECLAMATION BY REFORESTATION IN THE CENTRAL PYRENEES}

Since 1940 intensive reforestation has occurred in many of the mountain regions of Spain. Reforestation policies were introduced to meet a number of needs:

1. to create work for many unemployed persons following the end of the Spanish Civil War;

2. to control the hydrologic and geomorphic processes of slope erosion over large areas of open land with very little vegetative cover, especially in the south and Mediterranean regions that have suffered from human exploitation for centuries;

3. to improve the resource use of land that has been abandoned as the population moved away; in areas that have been completely abandoned institutional intervention to introduce reforestation measures is unobstructed;

4. to achieve self-sufficiency in the supply of pulp and paper resources, especially immediately after the Civil War; this need promoted the introduction of fast growing species.
These were the environmental and economic reasons behind the reforestation policies that were often the only State measures introduced, especially in extensive areas of the Spanish Pyrenees and to the south in the Prepyrenees. The effects of these policies on the ecosystems, from hydrologic and geomorphic view points, as well as from the biogeographical and land-use aspects, were remarkable. The effects on erosive processes and sediment transfer have been documented by Law (1956), Painter el al., (1974), and Murgatroyd and Ternan (1979); on the hydrology of slopes by Binns (1979); on land-use changes by Garcia-Ruiz (1976), and Valenzuela (1973); and the effects of reforestation on soil evolution have been discussed by Velasco and Albareda (1965) and Velasco (1968). This paper describes some of the chief characteristics of reforestation (techniques and species used) and the areas where it has been applied. To conclude, the primary results of extensive research by the Instituto Pirenaico de Ecologia on the diversity of growth related to environmental factors are discussed.

\footnotetext{
${ }_{1}^{1}$ Departamento de Geografia, Colegio Universitario de la Rioja, Logrono, Spain.

${ }^{2}$ Instituto Pirenaico de Ecologia, Apartado 64, Jaca (Huesca), Spain.

@International Mountain Society and United Nations University
} 


\section{THE GENERAL FEATURES OF REFORESTATION}

\section{Reforestation Poliaies}

Although there were forerunners, the present reforestation policies were introduced into Spain in 1940 by the Forest Administration (known as Patrimonio Forestal del Estado until 1971 and then as Instituto para la Conservacion de la Naturaleza-ICONA, Institute for Nature Conservation). At first, the effects in the Pyrenees were minimal, as the first reforestation plans were not carried out until 1946-1950 and they were not very important. After 1951 reforestation was intensified, sometimes involving entire townships, and it reached its maximum between 1956 and 1965. Since then it has decreased, partially due to budgeting problems, and partly because it proved difficult to reforest some very extensive areas as the remaining inhabitants continued to cultivate the land. In addition, public opinion, occasionally supported by scientists, has maintained an increasing opposition to reforestation policies. The period of maximum activity in the high Pyrenean valleys occurred slightly before that in the Prepyrenees.

Reforestation has been carried out on mountain lands under different ownership regimes. Initially, the State Forestry Department operated in areas that were State owned. Parallel to this, and later, they began to acquire private property and to expropriate communal land. Finally, they also established arrangements with the owners, generally town councils, to carry out reforestation;

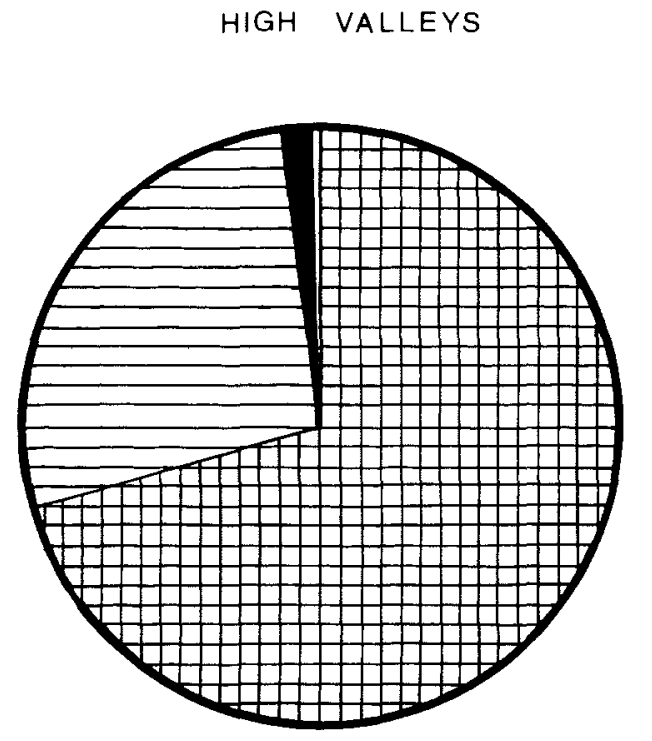

TOTAL 15,940 HA.

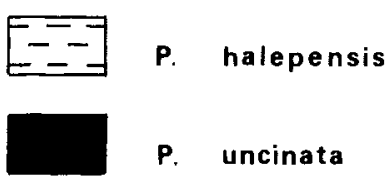

through such arrangements (consorcios) the State undertook replanting, but the property still belonged to the township and, as wood began to be produced, the profits were shared. However, replantation was most successful in those areas acquired by the State and the number of agreements with town councils has declined in recent years due to the local population's opposition to the loss of their communal land.

\section{Tree Speaies}

In the Spanish Pyrenees, as in most of Spain, reforestation has been based mainly on several pine species, but in some regions both public bodies and private owners have favored the use of Eucalyptus. The preference for pines is, first, because they are fast-growing trees and, in theory, lead to a quick soil hydrologic restoration and the formation of a protective vegetative cover. Secondly, the harvesting cycles are relatively short and there is a ready market for the wood in Spain, so it is a profitable choice. Finally, the diverse pine species are very adaptable to the ecological conditions of the Pyrenees where extensive natural pine forest exists. Moreover, the areas subject to reforestation are not in optimum condition; most soils are highly eroded and on slopes rainwater runoff is more prevalent than infiltration; planting of pines is less risky here as they serve as a pioneer species on waste land.

Figure 1 shows the proportion of the different pine

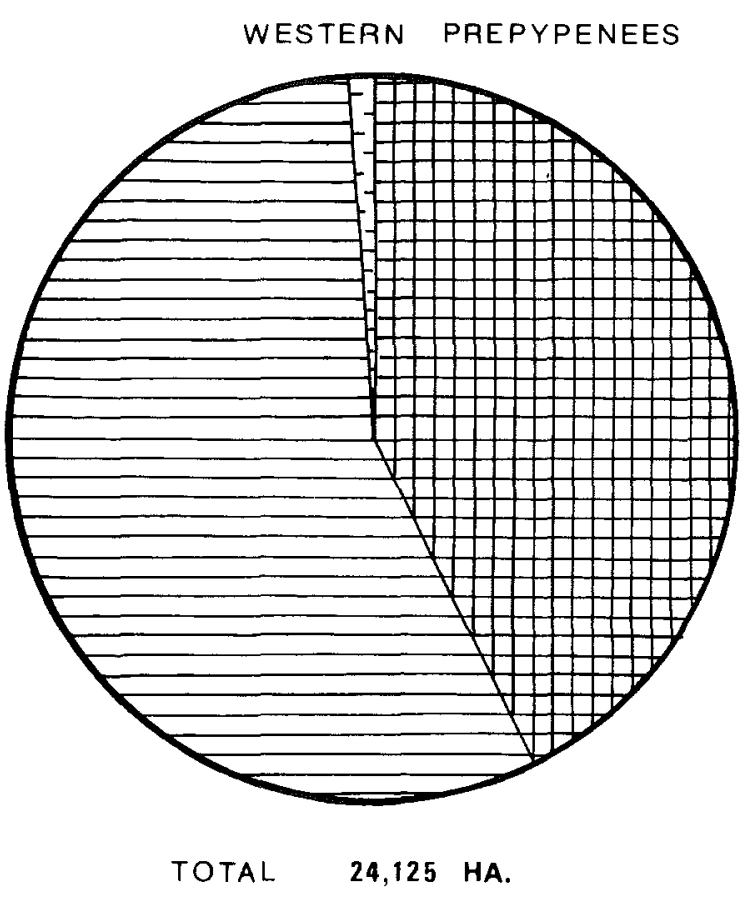

P. nigra

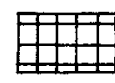

P. sylvestris

Figure 1. Species used for reforestation in the Central Pyrenees. 
species in the Pyrenees, according to data compiled by Valenzuela (1973) and Garcia-Ruiz (1976). There is a distinction between the high Pyrenean valleys to the north and the Prepyrenean region to the south; this is because of differing climatic and land-use conditions. In the high valleys Pinus sylvestris is predominant over Pinus nigra, while Pinus uncinata is found in small areas of the high-altitude slopes. In the Prepyrenees, on the other hand, Pinus nigra is the more important, and south-facing slopes and Mediterranean locations have been reforested by plantings of Pinus halepensis. Climatic factors underlie these differences, since in the high valleys precipitation is greater and the mean and extreme temperatures are lower; theoretically this makes Pinus sylvestris the preferred species. The Prepyrenean region is more Mediterranean and here Pinus nigra is used. At the local level, sunny slopes, are replanted only with Pinus nigra, especially at the lower levels; shady slopes and higher ones in sunny locations retain Pinus sylvestris plantings. Thus, topographical discrimination affects the spatial distribution of different tree species.

\section{Planting Technigues}

The first plantations were made by a system of digging holes (hollowing) and this method required abundant man- power. Plantations were usually small, although hundreds of hectares were planted by this method. In the 1950s and 1960 s oxen were used to dig furrows parallel to the contour lines and thus ease the task of planting. The advantage of this system was that there was less impact on the landscape, as the soil was tilled in a very local manner with no traumatic response. However, there was a major problem in the availability of oxen; the State Forestry Department had to buy and sustain them and this was an inconvenience. Furrowing still required manpower although it was less time-consuming than hollowing. In the late 1960s, caterpillar tractors and bulldozers were introduced to construct strips or terraces, consisting of a bench of several meters, a ridge on the border where the material from the terrace was accumulated, and a drop to the next terrace where generally the original shape and vegetation remained. Replanting by this method was much faster and required considerably less manpower - an important factor in regions undergoing depopulation. However, terracing alters the edaphic horizons. The upper horizons are eroded and accumulate on the next lower terrace leaving the $\mathrm{C}$ horizon exposed. When reforestation is very extensive the impact on the landscape is extreme and recovery takes a long time.

\section{CHARAGTERISTICS OF REFORESTED AREAS}

Below 1,800 m a.s.l., reforested areas are visible over almost all the Pyrenean range. Yet a closer approach indicates that reforestation tends to be clustered around the Central Pyrenees and is not so frequent in the Western Pyrenees. Even within the Central Pyrenees, the more southerly sections have been extensively affected by reforestation policies compared with those in the north. This is due mainly to climatic influences and the land-use system.

In the Pyrenees a double climate gradient is found. In the first instance, Atlantic influences decrease from west to east and Mediterranean influences increase: the Central Pyrenees exhibit a strong degree of continentality, with reduced precipitation and higher summer temperatures (Creus, 1983). In the second instance, there is a pronounced decrease in altitude from north to south, and in moisture from the north and northwest as the successive mountain ranges progressively block precipitation. This creates an accumulative rain shadow effect which produces a notable decrease in average precipitation while temperature and aridity in summer rise rapidly. As a consequence, the Western Pyrenees have a dense forest cover and greater potential for recuperation of vegetation on slopes degraded by human activity.

In the Central Pyrenees, however, after centuries of human exploitation, the forest has been relegated to midand high-valley slopes, and in the south to shaded slopes only. The recovery of abandoned land is more difficult due to extensive stony ground and the lack of water-retaining properties of the soils. Therefore, degradation of the landscape is most critical in the Prepyrenees, is less serious in the high valleys, and of least concern in the Western Pyrenees.

Present and traditional land-use patterns also serve to explain the distribution of reforestation. Historically, on the lower slopes of the Pyrenean valleys agriculture was the major activity; many areas were stable, terraced and permanently cultivated, while others with less favorable topography were used only occasionally and are now abandoned. Very few forests remain and these have thin soil; vegetative recovery rates are slow, water infiltration is minimal, and there are long summer droughts. These are the areas selected by the Forest Administration for hydrologic restoration.

These regions have also suffered rapid depopulation, losing more than 75 percent of their inhabitants during the twentieth century (Garcia-Ruiz, 1976). Agricultural activity is restricted to valley bottoms and perched flats, and elsewhere the land is being exploited by an extensive livestock-raising system with sheep now replaced by beef cattle. In an area with a highly degraded landscape, significant outmigration and an aging population, together with extensive land use, the State authorities have no obstacles to their reforestation policies.

Figure 2 shows the distribution of reforested areas in the Prepyrenees. In 1970, 22.7 percent of the land was controlled by the Forest Administration. The map indicates that some areas of reforestation are huge, and cover land once occupied by villages. The lower sections of high valleys have also been reforested. In some instances, such as in the Garcipollera, Guarga, and La Solana valleys, an integrated project involved the whole river basin and even 


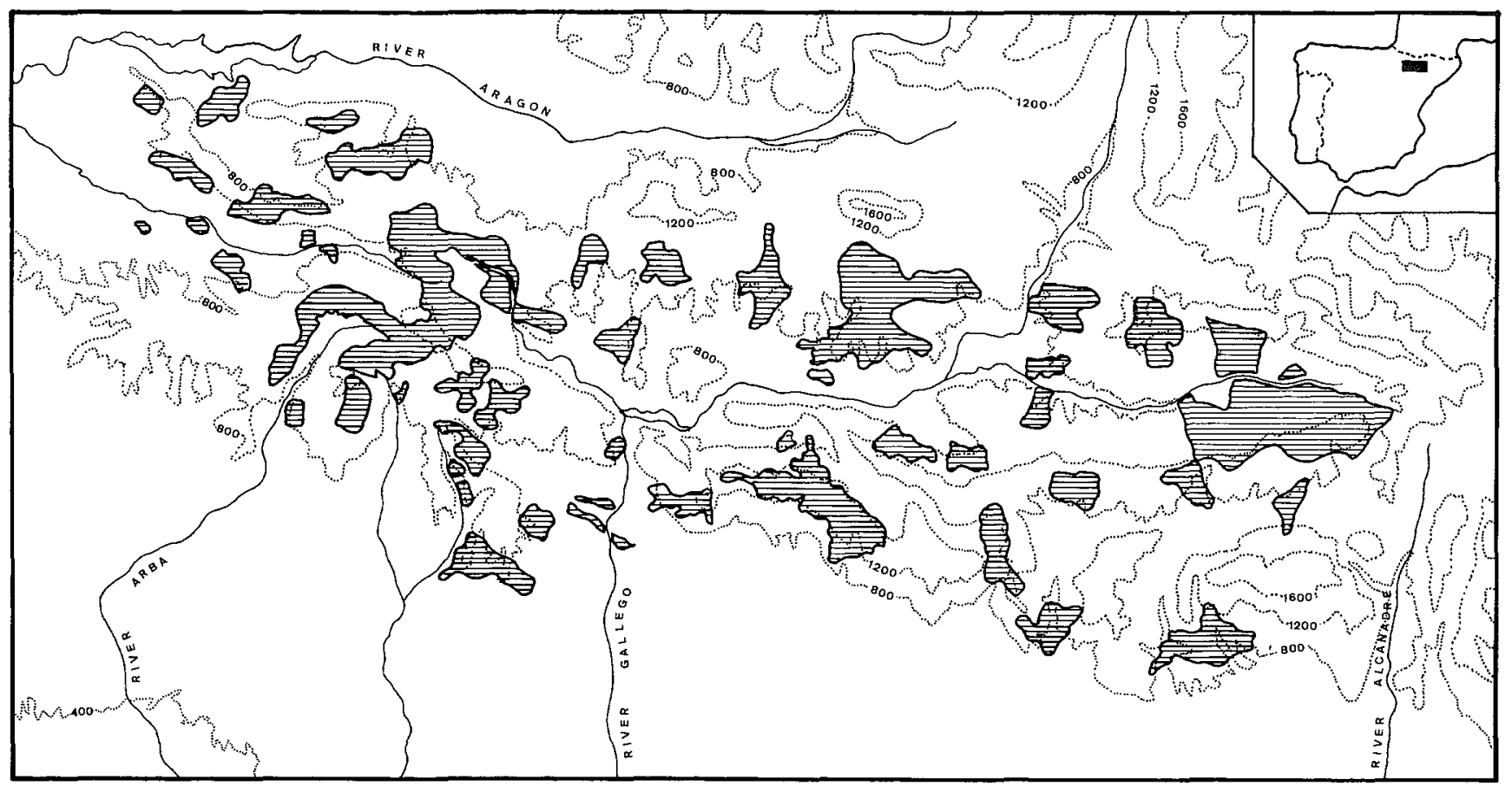

Figure 2. Areas of reforestation in the Prepyrenees.

riverbed restoration was included; sometimes large areas were expropriated and the population was forced to emigrate. In other instances, the activities were more specific in small or isolated units, usually in little used and degraded areas; here there were no expropriations but rather arrangements with the town councils or direct purchase from private owners.

Most reforested areas (70\%) are found below 1,100 m and almost half (44\%) lie between 800 and $1,100 \mathrm{~m}$, the belt traditionally exploited in the Central Pyrenees. The frequency of reforestation decreases remarkably at higher altitudes and the steeper slopes are hardly affected. Reforestation on slopes with gradients of less than 10 percent represents 42 percent of the total. This may seem surprising but the Forest Administration schemes involved flat valley bottoms and gentle slopes that had been cultivated in the past. Very steep slopes are seldom forested and where forests do exist they are often so degraded that recovery is impossible. Many of the reforestation schemes have been carried out on sandstone, clay, and silt alternatively; flysch slopes are also widely used while marls, which are generally intensively cultivated, have hardly been affected.

Reforestation projects on dam sites have somewhat different characteristics: the immediate objectives are to reduce sediment accumulation in order to prolong the life of the dam. In some instances, such as that of the Yesa Dam, emigration led to abandonment of agriculture and the land fell into the hands of the State through expropriation. Some of these areas of forest are very old, and even predate the Spanish Civil War; they are managed by the Ebro Hydrographical Confederation, an institution dedicated to dam construction. This Confederation acquired several properties in the La Pena basin (Gallego River) and reforested them with pine.

\section{THE RESULTS OF REFORESTATION POLICIES}

Most of the reforestation projects have affected large areas of land with very diverse environmental features. One would expect, therefore, that the projects would have important economic and social effects and also demonstrate great variability in degree of success. At the same time, some geomorphic consequences are evident although there is a lack of quantitative data.

From a socio-economic point of view, changes in land use relate to the area that is reforested and also to the agricultural practices of the local people. For instance, cattle are banned from reforested land for a number of years, sometimes up to twenty years, to prevent damage to the young trees. Grazing systems must therefore be changed and it may not be possible to maintain the same number of cattle. Farmers must keep close watch on the livestock and this may be difficult in the extensive system which prevails, especially as it is based on beef cattle. This in turn may cause discontent amongst the villagers and encourage them to leave. In some extreme cases, State authorities promoted total abandonment of the land when a large reforestation project was undertaken.

When grazing is forbidden for several years the pastures decline in quality (Montserrat, 1964). In those areas affected by reforestation, the preferred herbaceous species 
decline in both quality and number. By using the "complex" method of Sostaric and Kovacevik (1974) to determine pasture quality, it is concluded that pasture in unchanged areas (that is, under conditions similar to the original ones) is of low quality but in areas where the land use has been altered it is of even poorer quality. This confirms that forestation has a negative effect on sustainable productivity. State authorities do not always take this factor into account when making decisions.

During the decade of maximum activity (1956-1965) reforestation schemes provided wage labor for the local population and this resulted in a temporary increase in the standard of living. However, those people who had become accustomed to a regular income moved away from the area as soon as the employment opportunity ended. By the 1970s there was almost none of the inhabitants remaining and new reforestation projects required temporary laborers from other townships, or even from southern Spain (Garcia-Ruiz, 1976).

Most of the plantations are now more than fifteen years old and reliable data have become available. In the Central Pyrenees, 110 reforested plots were studied; trees, chosen at random, were measured and the mean annual growth rate was determined; Figure 3 shows the frequency distribution of these observations. Somewhat more than ten percent of the plots show stunted tree growth, and a similar percentage show optimum growth. Over 50 percent of the plots had an average growth of $10-20 \mathrm{~cm}$ per year, regarded as slightly inferior to that expected in the region. Zottl and Velasco (1966) point out that in regions with a humid or moderately dry climate (as in the Central Pyrenees) poor productivity is caused by lack of nitrogen in the soil and probably also by a shortage of potassium and phosphorous.

Considering that average tree size and age correlate strongly according to a linear function ${ }^{1}$, the residuals from the regression of tree height against the age of the plantation represent the relative weight of tree growth (Figure 4).

Thus, the remaining adjustments were used to contrast unequal tree growth of the plots. Later, by using a one-way analysis of variance (ANOVA) tree-growth rates and the different factors probably influencing them were compared. Field observations also gave data on the techniques employed (furrows or terraces), exposure, gradient, rocky substrate, and topographic position on the slope (crestlines, upper, medium, and lower slope sections). The most significant results were obtained from the study of topography and techniques.

On average, for all slopes there is a progressive increase in tree growth from the crest toward the base. At the foot of the slope there is a secondary reduction in tree growth. Such a phenomenon can be related mainly to moisture distribution over the slope and to its hydrologic functioning. The upper slopes produce water and material and have little capacity for water retention for the soils are thin.

\footnotetext{
${ }^{1}$ The linear function is of the type $y=a+b x$, the independent variable being reforestation age, and $y$ the average sizc observed on the trees of each plot.
}

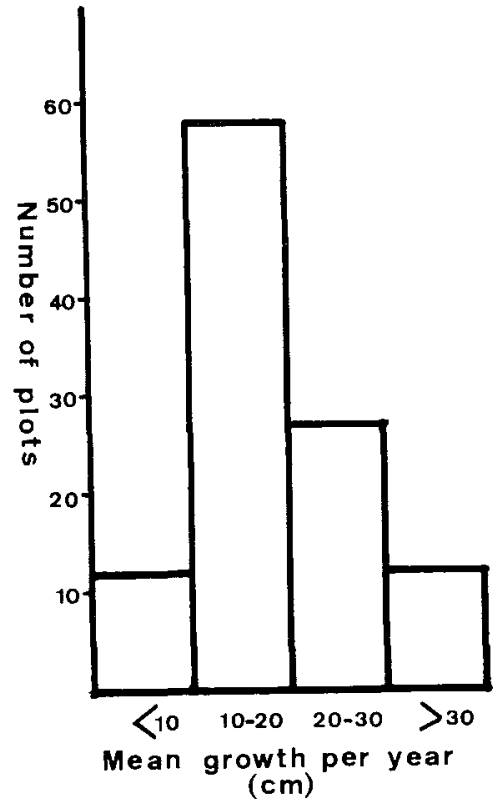

FiguRE 3 . The number and mean annual growth rate of reforested plots in the Central Pyrenees.

Toward the lower sections, water and nutrients are supplied from the upper areas, partly through the subsurface level, and summer drought is better withstood. Yet, although the lower parts may be expected to be the most fertile, this is not so. Many lower slopes have suffered severe human pressure from farming and this has resulted in loss of the upper soil layer due to excessive runoff; also they are usually areas close to main channels where gullies have caused environmental damage.

Although some lower slopes appear to be well preserved and have abundant tree growth, the more frequent occurrence of degraded land reduces the numerical tabulation of average tree growth.

When the techniques of replanting are studied, it can be observed that generally reforestation by furrowing gives better results than reforestation by terracing, even though the differences are not always significant. This tendency may be due to the alteration to soils by terracing as the most fertile horizon is displaced toward the terrace border. When topography is included in the analysis, it seems that terracing may give better results on upper slopes while furrowing is preferable elsewhere. This may be because soil water stress is greater close to the crestlines and the terrace system allows the retention of a greater proportion of water by preventing runoff; downslope, the more favorable hy drologic conditions are counterbalanced by terrace construction as water is no longer the limiting factor.

Rock type is seldom a significant factor in relation to tree growth after reforestation. However, on the upper slopes, impermeable substrates, such as clay and loams, are not as favorable as those of sandy substrates. Once again, there is confirmation of the hydrologic problem existing on watershed divides and surrounding areas; there is also confirma- 

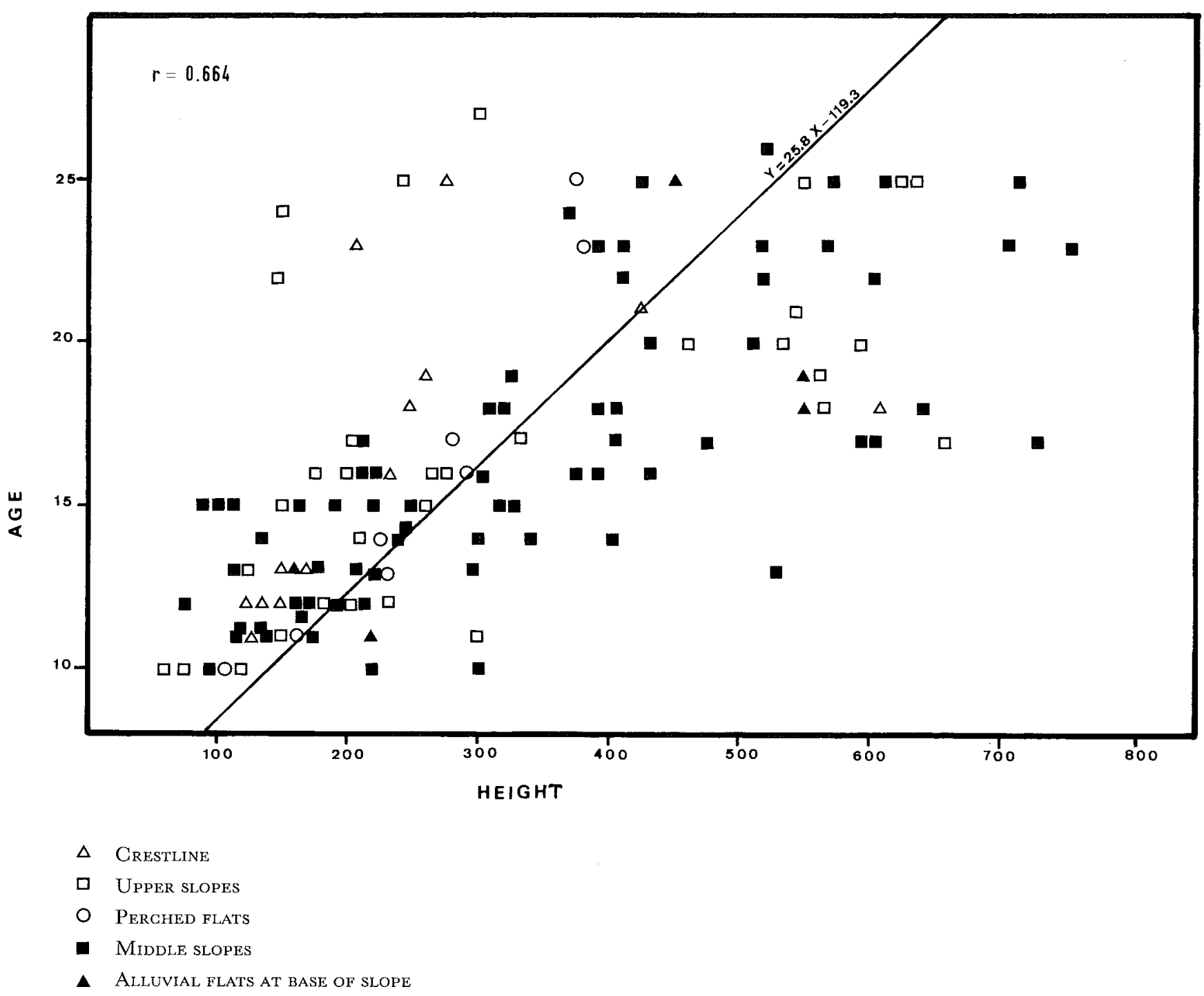

FIGURE 4. The relationship between mean height and age of reforested pines.

tion of the need to establish a more effective plantation system. Another significant result, althought of great complexity, is the fact that on sandy substrate, furrows are more suitable than terraces, while all techniques are equally effective on clay substrates. This is probably because the thin layer of soil on sandy substrates is easily destroyed by the machinery used in building the terraces; on the other hand, when a sandy substrate supports deep soils, it is of top quality and therefore becomes strongly affected by sudden alteration; those soils lying on clays are inherently poor, and terrace construction incurs no damage.

Finally, it is not easy to relate the diverse effects of reforestation to geomorphic factors. In a study of Pyrenean flysch slopes, Garcia-Ruiz and Puigdefabregas (1982) concluded that erosion phenomena are more frequent and intense: (i) on those slopes formerly under cultivation and subsequently abandoned; (ii) on slopes that are undergoing a process of brushwood revegetation, and (iii) on reforested slopes.
This does not imply that reforestation projects are responsible for such geomorphic activity; but at least it can be concluded that replanting cannot prevent completely highmagnitude events, especially mass movements. Some slippage processes also seem to be accelerated by terrace construction, especially on very steep slopes and clay substrates, where Atterberg limits are soon reached. Other authors (Binns, 1979) point out that in the primary stages, reforestation results in an increase in the transfer of solid material to river beds owing to environmental disturbance; yet, only a few years later sediment concentration is much less. Murgatroyd and Ternan (1983) do not refer to the hydrologic behavior of reforested slopes, although they mention an intensification of river bank erosion in Great Britain, phenomena that we consider inapplicable to subMediterranean regions. 

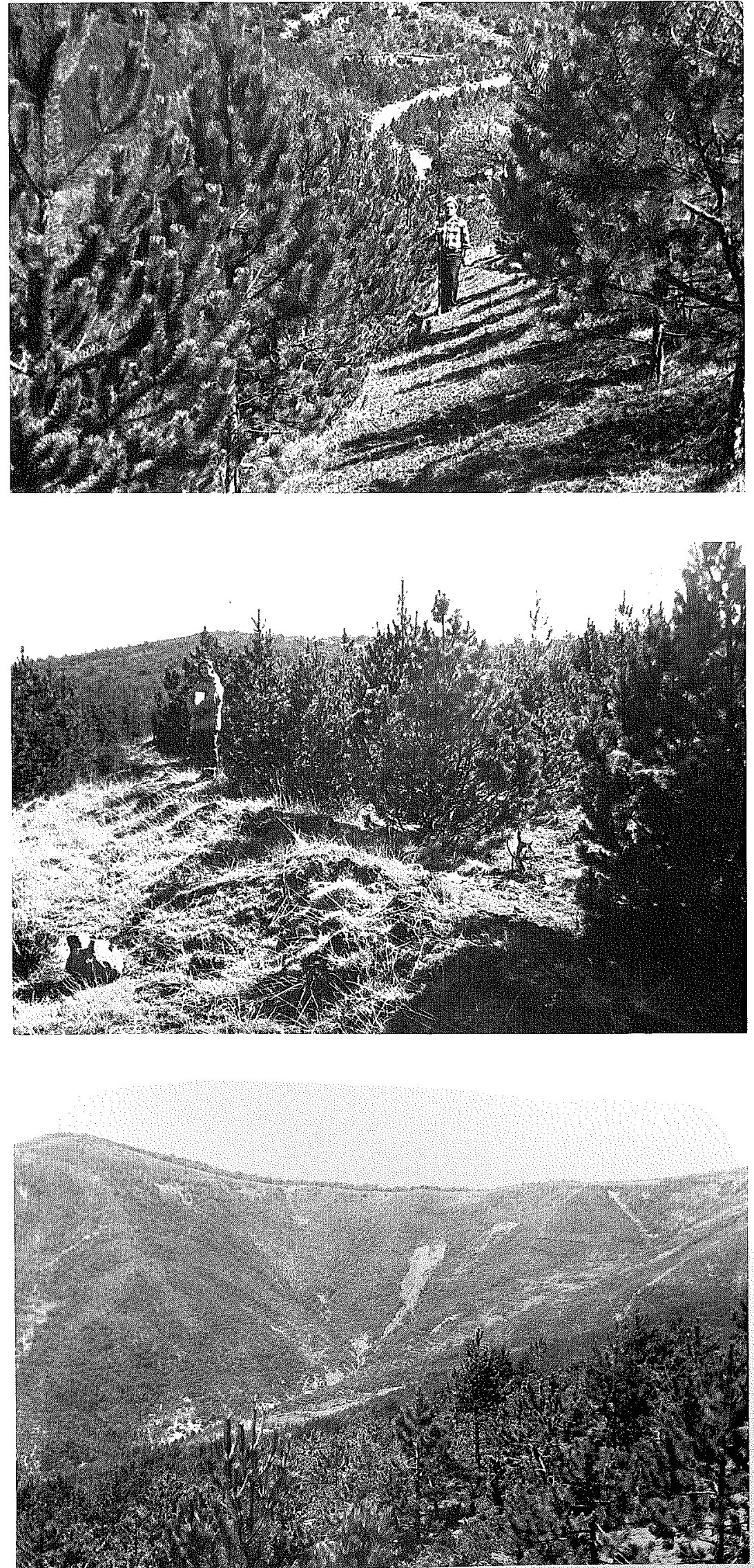

Reforestation with construction of furrows and ridges on marly soils; seventeen years after planting there is a good growth of Pinus nigra.

Reforestation by furrowing in the southernmost part of the Pyrenees; the photograph shows the topographic modification used in this technique, with a low ridge to retain overland flow.
Reforestation in the Garcipollera Valley; the entire valley was replanted with Pinus nigra and $P$ sylvestris during the 1960 s; the valley sides were cultivated until the general abandonment of the region; severe sheet wash erosion and mass movement are evident now. 


\section{GONCLUSIONS}

Reforestation is probably the method most frequently chosen by public authorities to resuscitate marginal regions that have been severely degraded by traditional land-use practices and are experiencing rapid depopulation. In the Spanish Pyrenees during the last thirty years, and especially in the 1960s and 1970s, the abandonment of land and serious erosion led to extensive reforestation, involving over 25 percent of the area. The most affected region is the Prepyrenees, due to the more Mediterranean climate and the large area of lower, sunny slopes of the high valleys. After 1975, reforestation decreased owing to the strong protests of the local population and conservation associations. The only species introduced into the Pyrenees were pine, planted first by the "hollow" system, later by furrowing, and more recently by terracing with

\section{REFERENCES}

Binns, W. O., 1979: The hydrological impact of afforestation in Great Britain. In Hollis, G. E. (ed.), Man's impact on the hydrological cycle in the United Kingdom, Norwich, England, pp. 55-70.

Creus-Novau, J., 1983: El Clima del Alto Aragon Occidental. Monografias del Inst. de Estudios Pirenaicos, 109. 233 pp.

Garcia-Ruiz, J. M., 1976: Modos de vida y niveles de el Prepirineo del Alto Aragón Occidental. Instituto de Estudios Pirenaicos, Jaca, Spain. 272 pp.

Garcia-Ruiz, J. M. and Puigdefabregas, J., 1982: Formas de erosión en el flysch eoceno surpirenaico. Cuadernos de Investigación Geográfica, 8: 85-130.

Law, F., 1956: The effect of afforestation upon the yield catchment areas. Journal of the British Waterworks Association, 38: 489-494.

Montserrat, P., 1964: Ecologia del pasto. Publ. del Centro Pirenaico de Biol. Experimental, 1 (2): 1-68.

Murgatroyd, A. L. and Ternan, J. L., 1983: The Impact of afforestation on stream bank erosion and channel form. Earth Surface Processes and Landforms, 8: 357-369.

Painter, R. B., Blyth, K., Mosedale, J. C., and Kelly, M., 1974: the use of heavy machinery.

The widespread reforestation has had very important impacts on the local people. Cattle raising has been reorganized, the area of pasture has been reduced, and forestation activity over extensive areas has accelerated population drift. Pastures have been damaged and the quality of cattle fodder has been reduced.

The relationship between tree growth and environmental factors emphasizes the importance of slope hydrologic functioning: reforestation in the upper and drier sections is less successful, and only by using drastic correction methods (terraces) can acceptable results be achieved. On mid- and lower-slopes reforestation is an effective method of land reclamation.

The effect of afforestation on erosion processes and sediment yield. International Association of Scientific Hydrology Publication, 113: 62-67.

Sostaric, K. and Kovacevic, J, 1974: La Méthode "Complexe" pour la détermination de la qualité et de la valeur globale des herbages et des prairies temporaires. Fourrages, 60: 3-25.

Valenzuela, M. G., 1973: Repoblación forestal en el Alto Pirinco aragonés. Geographica, 15 (1): 33-43.

Velasco, F, 1968: Variaciones en la composición y naturaleza de las sustancias húmicas de un suelo climax de Quercus toza pro ducidas por la implatación de Pinus pinaster. Anales de Edafología y Agrobiología, 27 (5-6): 389-398.

Velasco, F. and Albareda, J. M., 1965: Evolución de un suelo de bosque Quercus pyrenaica provocada por una plantación de Pinus sylvesiris. Anales de Edafología y Agrobiología, 24 (11-12): 623-631.

Zöttl, H. W. and Velasco, F., 1966: Estado nutritivo y crecimiento de diversas repoblaciones del género Pinus en España. Anales de Edafologia y Agrobiología, 25 (5-6): 249-268. 